\begin{tabular}{|ll|}
\hline Received & $:$ 30 Maret 2019 \\
Revised & $:$ A April 2019 \\
Accepted & $:$ 22 April 2019 \\
Online & $:$ 28 April 2019 \\
Published & $:$ 30 April 2019
\end{tabular}

\title{
PRODUK KOLEKBINDO (KOMIK LEKSIKON BAHASA INDONESIA) SEBAGAI MEDIA SOSIALISASI KONSEP KATA DALAM BAHASA INDONESIA
}

\author{
Anisa Setiani' ${ }^{1)}$, Hermawati' ${ }^{2}$, dan Mufidah Nur Azizah ${ }^{3)}$ \\ ${ }^{1}$ Fakultas Bahasa dan Seni, Universitas Negeri Jakarta \\ ${ }^{2}$ Fakultas Bahasa dan Seni, Universitas Negeri Jakarta \\ ${ }^{3}$ Fakultas Bahasa dan Seni, Universitas Negeri Jakarta \\ email: 28mufi@gmail.com
}

\begin{abstract}
Indonesian language society still has minimal knowledge and lowly comprehension about the concept of words in Indonesian language. This phenomenon raises conflicts, one of them is misconceptions between speakers. Solution that can be done is the socialization of concept of Indonesian words. Based on that solution, this research produces new product to socialize the concept of Indonesian words called Kolekbindo (Komik Leksikon Bahasa Indonesia), namely the socialization media of concept of Indonesian words-based comic strips digital spreaded through social media. The method which is used on this research is $R \& D$ method (Research and Development). The purpose of this research is to produce new socialization media of Indonesian words. The results of this research can be described as: (1) Kolekbindo has an attractive style of paint and colour combination; (2) The layout is neat; (3) The type and size of the font is clear and the contents are easy to understand; (4) Contrasting characters and unique names is so interesting; and (5) Kolekbindo beneficial of being a media to socialize the Indonesian word's concepts. Based on the results of the questionnaire, Kolekbindo's usefulness as a socialization media of Indonesian words has a percentage of $85.80 \%$ with very good criteria.
\end{abstract}

Keywords: Kolekbindo, Socialization, Concept of Words, Indonesian Language

\begin{abstract}
Abstrak
Masyarakat bahasa Indonesia masih memiliki pengetahuan minimal dan pemahaman yang rendah tentang konsep kata dalam bahasa Indonesia. Fenomena ini menimbulkan konflik, salah satunya adalah kesalahpahaman antar pembicara. Solusi yang bisa dilakukan adalah sosialisasi konsep kata-kata Indonesia. Berdasarkan solusi tersebut, penelitian ini menghasilkan produk baru untuk mensosialisasikan konsep kata-kata bahasa Indonesia yang disebut Kolekbindo (Komik Leksikon Bahasa Indonesia), yaitu media sosialisasi konsep komik Indonesia berbasis kata-kata strip digital yang disebarkan melalui media sosial. Metode yang digunakan dalam penelitian ini adalah metode R\&D (Penelitian dan Pengembangan). Tujuan dari penelitian ini adalah untuk menghasilkan media sosialisasi baru kata-kata Indonesia. Hasil penelitian ini dapat digambarkan sebagai: (1) Kolekbindo memiliki gaya cat yang menarik dan kombinasi warna; (2) Tata letaknya rapi; (3) Jenis dan ukuran font jelas dan isinya mudah dimengerti; (4) Karakter kontras dan nama unik sangat menarik; dan (5) Kolekbindo bermanfaat sebagai media untuk mensosialisasikan konsep kata Indonesia. Berdasarkan hasil kuesioner, kegunaan Kolekbindo sebagai media sosialisasi kata-kata Indonesia memiliki persentase $85,80 \%$ dengan kriteria sangat baik.
\end{abstract}

Kata kunci: Kolekbindo, Sosialisasi, Konsep Kata-kata, Bahasa Indonesia. 


\section{PENDAHULUAN}

Bahasa Indonesia adalah bahasa persatuan bangsa Indonesia. Bahasa Indonesia berfungsi sebagai alat ekspresi diri, identitas, dan komunikasi antarmasyarakat bahasa rakyat Indonesia yang beraneka ragam. Bahasa Indonesia berperan sebagai wadah penyampai informasi dan aspirasi. Oleh karena itu, tepat atau tidaknya diksi dalam berbahasa dapat memengaruhi mutu informasi yang tersampaikan. Apabila penutur salah memilih kata dan menyebabkan ketaksaan penerimaan informasi, konflik atau kesalahpahaman dapat timbul. Seperti pada masa kini, tidak jarang masyarakat Indonesia menerima hoaks mentah-mentah, tersulut emosinya, hingga memicu perang pendapat antarkubu karena kurangnya pengetahuan dan pemahaman mengenai pengertian masing-masing kata dalam kosakata bahasa Indonesia.

Dalam Seminar Nasional Bahasa dan Sastra Indonesia yang diadakan pada 5 Desember 2017 lalu, Dadang Suhendar selaku Ketua Badan Pengembangan Bahasa dan Perbukuan menuturkan bahwa pendefinisian beberapa kata di KBBI masih belum cukup baik menjelaskan konsep kata tersebut. Artinya, sosialisasi konsep kata-kata bahasa Indonesia melalui produk-produk yang dihasilkan oleh instansi pemerintahan yang berwenang masih memiliki keterbatasan.

Media sosial terdiri dari kata "media" dan "sosial". Kata "media" diartikan sebagai alat komunikasi (Laughey, 2007; McQuail, 2003). Sementara, kata "sosial" artinya kenyataan sosial bahwa setiap individu melalukan aksi yang memberikan konstribusi kepada masyarakat. Durkheim (dalam Fuchs, 2014:38) menjelaskan bahwa media dan perangkat lunak merupakan produk dari proses sosial.

Secara umum, media sosial adalah sebuah media untuk bersosialisasi satu sama lain dan dilakukan secara online yang memungkinkan manusia untuk saling berinteraksi tanpa dibatasi ruang dan waktu. Komik menurut Franz dan Meier (dalam Nurgiyantoro, 2005:410) adalah cerita yang bertekanan pada gerak dan tindakan yang ditampilkan pada urutan gambar yang dibuat secara khas dengan paduan katakata. McCloud (2001:9) juga menyatakan konsep komik yaitu gambar-gambar serta lambang lain yang terjukstaposisi (berdekatan atau bersebelahan) dalam urutan tertentu untuk menyampaikan informasi dan/atau mencapai tanggapan estetis dari pembacanya.

Komik bukan hanya bacaan bagi anak-anak. Namun, komik adalah bentuk media komunikasi visual yang mempunyai kekuatan untuk menyampaikan informasi secara popular dan mudah dimengerti. Hal ini karena komik memadukan gambar dan tulisan. Teks yang ada di komik membuat informasi lebih dimengerti, sedangkan alur membuat informasi menjadi lebih mudah untuk diingat dan dipahami.

Komik juga memiliki jenis-jenisnya. Pertama, komik kartun atau karikatur. Karikatur hanya memiliki satu tampilan yang berisi beberapa karakter yang digabungkan dengan tulisan. Kedua, komik potongan atau strip comic. Komik potongan adalah penggalan gambar yang digabungkan menjadi satu bagian atau sebuah alur cerita pendek (cerpen).

Ketiga, komik tahunan atau annual comic. Komik ini biasanya terbit setiap sebulan atau setahun sekali. Penerbit biasanya menerbitkan buku komik itu berupa cerita putus atau serial. Keempat, komik online atau webcomic. Komik ini disebut komik digital karena memanfaatkan kecanggihan internet dan media sosial dalam menyebarkan atau memasarkannya. Kelima, buku komik. Buku komik dikemas dalam bentuk buku dengan cerita yang memuat gambar dan tulisan. Buku komik disebut sebagai komik cerita pendek yang biasanya terdiri dari berisikan 32, 48, atau 64 halaman.

Kosakata berasal dari bahasa Sanskerta yaitu koça yang artinya pembendaharaan, kekayaan, khazanah dan khata yang artinya kata. Demikian, secara etimologi, kosakata adalah pembendaharaan kata. Menurut Notosudirjo (dalam Chaer, 2007:6) kosakata adalah (1) semua kata yang terdapat dalam suatu bahasa; (2) kata-kata yang dikuasai oleh seseorang atau sekelompok orang dari lingkungan yang sama; (3) kata-kata atau istilah yang digunakan dalam satu bidang kegiatan atau ilmu pengetahuan; (4) sejumlah kata dari suatu bahasa yang disusun secara alfabetis berserta sejumlah penjelasan maknanya; dan (5) sebuah morfem yang ada dalam suatu bahasa.

Kosakata bahasa Indonesa sudah ada sejak Indonesia sendiri belum merdeka. Suhardi dan Sembiring (dalam Kushartanti, Untung Yuwono, dan Multamania RMT Lauder, 2009:61) menyatakan bahwa kata atau ragam bahasa yang baku telah mencapai tahap pembakuan dari segi tata bahasa, ejaan, dan kosakatanya. Biasanya disebut bahasa standar atau baku yang dalam pemakaiannya lebih sering 
ditemukan dalam tulisan daripada tuturan. Namun, keadaan di lapangan banyak mengungkapkan bahwa pemakaian yang tidak baku juga merebak ke lingkup bahasa tulisan.

Kata baku menurut Kosasih dan Hermawan (2012:83) adalah kata yang cara pengucapan ataupun penulisannya sesuai dengan kaidah-kaidah yang dibakukan. Kaidah standar tersebut ialah Ejaan yang Disempurnakan (EYD), tata bahasa baku, dan kamus. Penggunaan kata baku adalah konteks ragam baku lisan dan tulisan. Ragam bahasa yang baku dapat dibatasi oleh sudut pandang kebakuan bahasa yang digunakan, sudut pandang informasi, dan sudut pandang pengguna bahasa (Moeliono dalam Chaer, 2011:5).

Kasus mengenai kesalahan pemilihan kata karena minimnya pengetahuan akan makna kata tersebut semakin sering kita dapati pada era digital. Kasus ini, apabila berkesinambungan terus terjadi, dapat mengancam bahasa. Kesalahpahaman mengenai konsep suatu kata yang terbiasa digunakan bisa menjadi lazim dan berterima, meskipun menyalahi kaidah yang berlaku.

Oleh karena dampak dari kurangnya pengetahuan akan konsep kata-kata bahasa Indonesia ini begitu luas, kami menyadari pentingnya membuat suatu gagasan baru dalam memasyarakatkan konsep kata, khususnya kata baku, sehingga dibuat produk penyampai konsep kata yang ringan, komunikatif, edukatif, dan memiliki sasaran konsumen yang luas bernama Kolekbindo (Komik Leksikon Bahasa Indonesia).

Implementasi Kolekbindo pada pengguna media sosial, dapat merepresentasikan pemerian kosakata bahasa Indonesia dengan tampilan yang lebih menarik, fleksibel, dan ringan serta dapat menjadi salah satu pendekatan baru yang menyegarkan dalam memasyarakatkan konsep kata-kata baku bahasa Indonesia.

\section{METODE PENELITIAN}

Penelitian ini dilakukan selama lima bulan yaitu dari bulan April sampai Agustus 2018 di Kampus A Universitas Negeri Jakarta. Tujuan operasional dari penelitian ini adalah untuk memperoleh data dan informasi dalam mengetahui apakah produk Kolekbindo atau Komik Leksikon Bahasa Indonesia efektif sebagai media sosialisasi konsep kata yang baku dalam bahasa Indonesia. Objek yang digunakan adalah komik.

Penelitian ini menggunakan metode penelitian dan pengembangan atau (research and development). Metode $\mathrm{R} \& \mathrm{D}$ yang kami gunakan adalah rekomendasi Sukmadinata dengan menerapkan modifikasi yang lebih sederhana. Sukmadinata (2010:164) menyebutkan bahwa penelitian dan pengembangan adalah suatu proses atau langkah-langkah untuk mengembangkan produk yang telah ada, yang dapat dipertanggungjawabkan.

Populasi yang ada di dalam penelitian ini adalah pengguna media sosial Instagram, Twitter, dan Facebook dengan usia 13 sampai 34 tahun. Metode sampling yang digunakan adalah purposive sampling. Sampel yang ada di dalam penelitian ini adalah pengikut akun @Kolekbindo di akun Instagram, Twitter, dan Facebook yang berjumlah 37 orang berdasarkan rumus berikut. (Zainuddin, 2002:58). 


$$
\begin{aligned}
& n=\frac{Z^{2} \frac{a}{2} * p(1-p) N}{d^{2}(N-1)+Z^{2} \frac{a}{2} * p(1-p)} \\
& n=\frac{(1,96)^{2} * 0,55(1-0,55) 63}{(0,1)^{2}(63-1)+1,96^{2} * 0,55(1-0,55)} \\
& n=\frac{3.8416 * 0,55(128,35)}{0,01(62)+0,950796} \\
& n=\frac{59,4791505}{1,570796} \\
& n=37,8656111296 \\
& n=37
\end{aligned}
$$

yang mana

$\begin{array}{lll}\mathrm{n} & = & \text { besar sampel } \\ Z^{2} \frac{a}{2} & = & \begin{array}{l}\text { nilai } Z \text { pada derajat } \\ \text { kepercayaan } 1-\frac{a}{2}(1,96)\end{array} \\ \mathrm{p} & = & \begin{array}{l}\text { proporsi hal yang diteliti } \\ (0,55)\end{array} \\ \mathrm{d} & = & \begin{array}{l}\text { tingkat ketepatan yang } \\ \text { diinginkan }(0,1)\end{array} \\ \mathrm{n} & = & \text { jumlah populasi }(63)\end{array}$

Teknik pengumpulan data atau instrumen penelitian yang digunakan adalah wawancara dan kuesioner. Wawancara digunakan sebagai teknik pengumpulan data apabila peneliti ingin melakukan studi pendahuluan untuk menemukan permasalahan yang harus diteliti, tetapi juga apabila peneliti ingin mengetahui hal-hal dari responden yang lebih mendalam (Sugiyono, 2013:231).

Wawancara di dalam penelitian ini dilakukan secara individual. Dengan mengajukan pertanyaan sesuai permasalahan media sosialisasi dalam penggunaan bahasa Indonesia yang baik dan benar yang masih kurang memadai.

Angket atau kuesioner merupakan suatu teknik atau cara pengumpulan data secara tidak langsung (Sukmadinata, 2010:219).

Kuesioner di dalam penelitian ini dibuat dengan skala bertingkat yaitu terdapat sebuah pertanyaan dengan kolom-kolom yang menunjukkan tingkatan, seperti sangat setuju, setuju, ragu-ragu, kurang setuju, dan tidak setuju yang diwakilkan oleh angka 1 sampai dengan angka 5. Angket ini ditujukan bagi masyarakat umum usia 13-34 tahun.

Teknik analisis data di penelitian ini adalah dengan menggunakan skala Linkert. Sugiyono (2010:134) menyatakan bahwa skala Linkert digunakan untuk mengukur sikap, pendapat, dan persepsi seseorang atau sekelompok orang tentang fenomena sosial.

Karena skala Linkert menggunakan angka 1 s.d. 5, maka rentang kelasnya bisa ditentukan yaitu data terbesar dikurang data terkecil atau 5-1 adalah 4. Setelah rentang kelas ditentukan, bisa dicari interval kelasnya yaitu sebagai berikut (Sudjana, 2005:47).

$$
\begin{aligned}
\text { Interval kelas }(P) & =\frac{\text { Rentang Kelas }}{\text { Banyaknya Kelas }} \\
& =\frac{4}{5} \\
& =0,8
\end{aligned}
$$

Dengan begitu, jarak antarkriteria adalah 0,8 atau $16 \%$ dalam persentase. 
Tabel 1. Interval Kelas Media Sosialisasi Kolekbindo

\begin{tabular}{ccc}
\hline No. & Rentang Skor Interval & Kriteria \\
\hline 1. & $4,20<$ skor $\leq 5$ & Sangat Baik \\
2. & $3,40<$ skor $\leq 4,20$ & Baik \\
3. & $2,60<$ skor $\leq 3,40$ & Cukup \\
4. & $1,80<$ skor $\leq 2,60$ & Kurang Baik \\
5. & $1 \leq$ skor $\leq 1,80$ & Tidak Baik \\
\hline
\end{tabular}

Tabel 2. Interval Kelas Media Sosialisasi Kolekbindo dalam Persentase

\begin{tabular}{ccc}
\hline No. & Rentang Skor Interval & Kriteria \\
\hline 1. & $84 \%<$ persentase $\leq 100 \%$ & Sangat Baik \\
2. & $68 \%<$ persentase $\leq 84 \%$ & Baik \\
3. & $52 \%<$ persentase $\leq 68 \%$ & Cukup \\
4. & $36 \%<$ persentase $\leq 52 \%$ & Kurang Baik \\
5. & $20 \%<$ persentase $\leq 36 \%$ & Tidak Baik \\
\hline
\end{tabular}

Di dalam penelitian ini, peneliti menetapkan bahwa media sosialisasi Kolekbindo dikatakan layak digunakan apabila berada pada kriteria baik yaitu dengan skor lebih dari 3,40 dan persentasi lebih dari $68 \%$.

Untuk mengetahui hasil akhir kriteria kelayakan, angka-angka yang akan didapat setelah menyebarkan kuesioner nanti bisa diolah dengan rumus sebagai berikut.

$$
K=\frac{\text { skor semua responden }}{\text { jumlah responden } X \text { jumlah pernyataan }}
$$

Selanjutnya, tahap-tahap dalam membuat Kolekbindo adalah di bawah ini yang dimulai dari tahap pendahuluan, tahap pengembangan, tahap validasi, dan tahap pengujian.

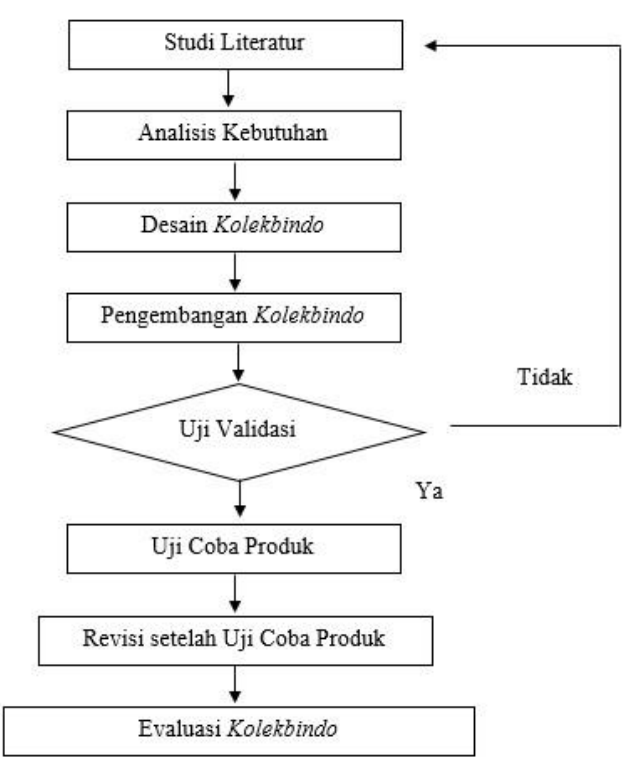

Gambar 1. Diagram Alur Prosedur Kolekbindo 


\section{Tahap Pendahuluan}

Setelah mencari data literatur, kami mengobservasi masyarakat umum untuk mengetahui kebutuhan sosialisasi kosakata bahasa Indonesia serta media sosialisasi apa yang tepat. Observasi itu disebut juga analisis kebutuhan. Proses tersebut diadakan dengan menggunakan metode wawancara terhadap lima orang responden.

Pertanyaan wawancaranya berputar pada apa pentingnya pemahaman masyarakat terhadap bahasa Indonesia, penggunaan kata yang baku, peran pemerintah, bentuk media sosialisasi yang baik dan benar, serta preferensi antara media digital atau cetak.

\section{Tahap Pengembangan}

Pada tahap pengembangan langkah awal yang dilakukan adalah mengumpulkan leksikon apa yang akan dijadikan konten cerita, membuat karakter komik yang terdiri dari Mawa, Upit, dan Acis, menentukan alur ceritanya yang bisa dimuat dalam 6-10 panel saja, mendesain gambar awal di kertas, baru kemudian mengubahnya menjadi digital.

Pada konten pertama, kami membahasa tentang kata "gawai". Di dalam cerita, dikisahkan bahwa Mawa memiliki ponsel baru dan Acis meledeknya dengan mengatakan "gawai baru". Upit yang tidak tahu kata gawai, bertanya-tanya apa itu artinya. Kemudian, Mawa menjelaskan bahwa gawai adalah padanan kata dari handphone.

Pada konten kedua, kami membahas tentang kata "daring". Di dalam cerita, dikisahkan bahwa Mawa memberitahukan kepada Acis kalau mereka akan melakukan kuliah daring di malam hari. Kemudian, Acis mengira bahwa mereka kuliah seperti biasa malam-malam. Padahal, makna "kuliah daring" sendiri adalah kuliah yang dilakukan lewat internet.
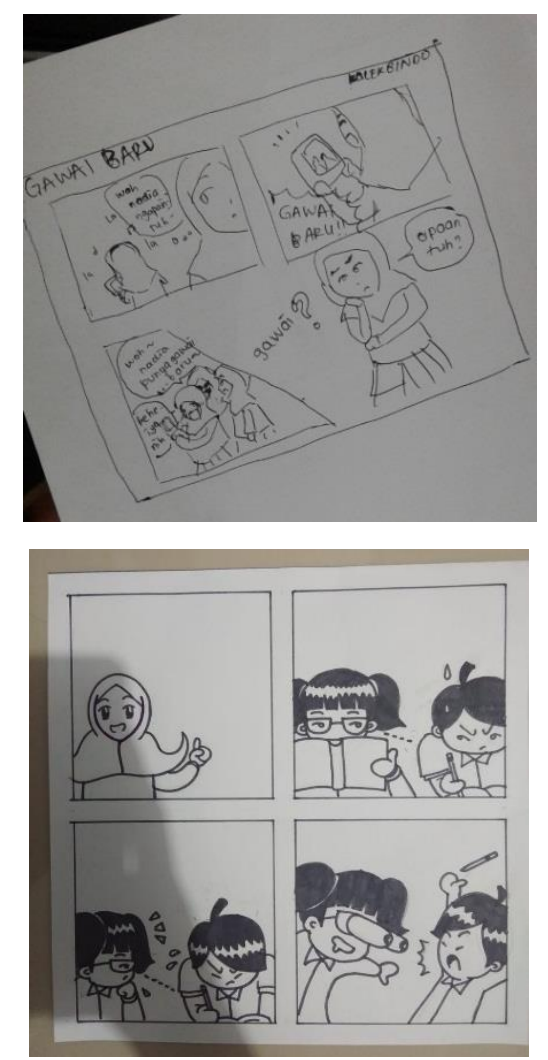

Gambar 2. Desain Awal Konten Kolekbindo 

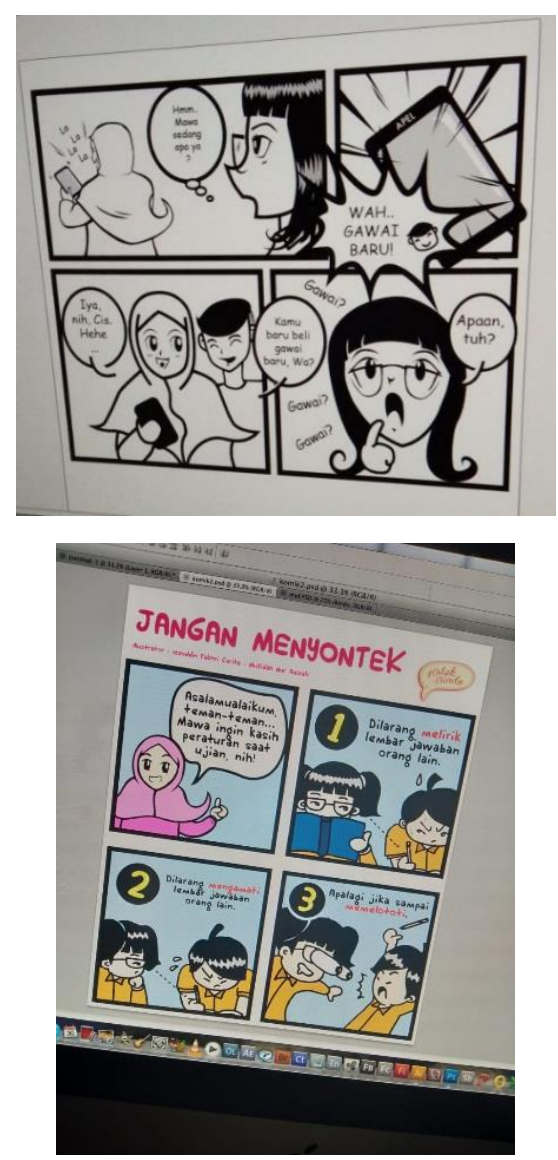

Gambar 3. Desain Kolekbindo di Photoshop

Selanjutnya, setelah selesai dengan urusan komik dan isinya, kami berlanjut ke urusan media sosialnya yaitu mulai dari membuat logo Kolekbindo serta membuat akun Instagram, Twitter, dan Facebook.

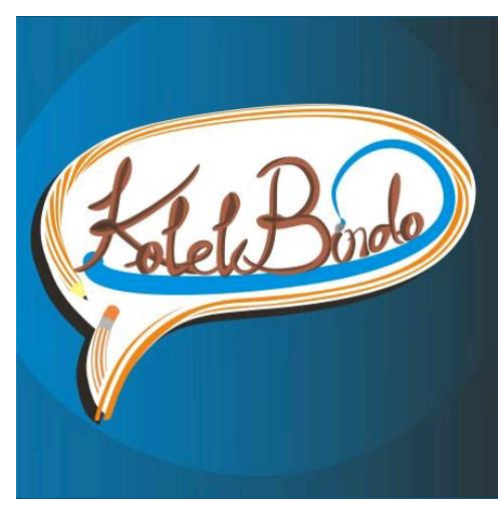

Gambar 4. Logo Kolekbindo 


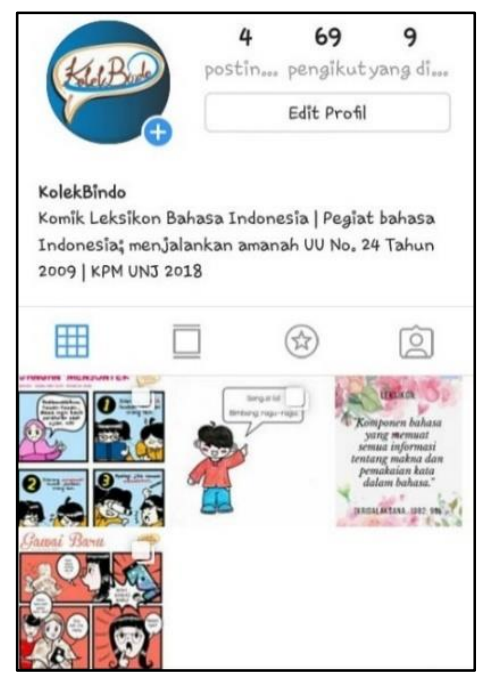

Gambar 5. Akun Instagram Kolekbindo

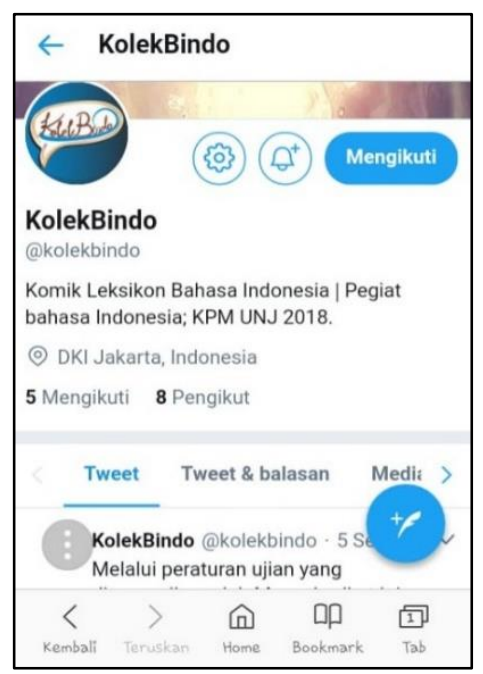

Gambar 6. Akun Twitter Kolekbindo

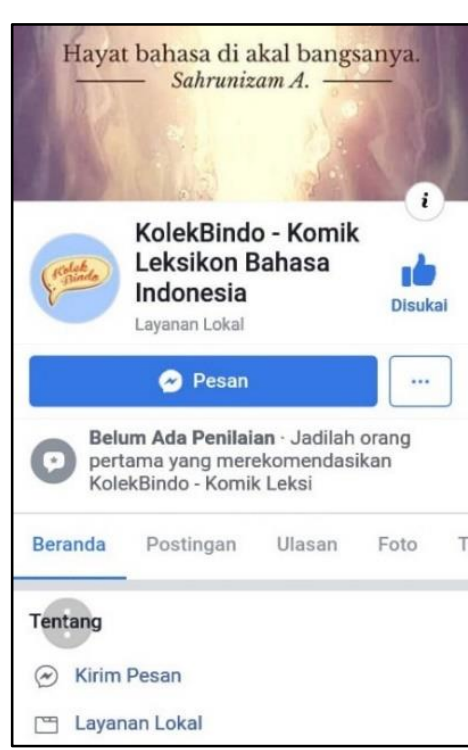

Gambar 7. Akun Facebook Kolekbindo 


\section{Tahap Validasi}

Kami melakukan validasi setelah melewati tahap pengembangan komik. Validasi terhadap Kolekbindo ini terdiri dari dua aspek yaitu aspek media dan materinya. Keduanya dilakukan oleh Dr. Miftahulkhairah Anwar, M.Hum. pada 28 Agustus 2018. Uji validitas media Kolekbindo bertujuan memvalidasi segala hal yang berkaitan dengan komponen komik seperti warna, tata letak, dan bentuk tulisan. Sementara, uji validitas materi Kolekbindo bertujuan memvalidasi isi atau konten cerita di dalam Kolekbindo apakah sudah layak atau belum.

Uji validitas media terdiri dari 9 pernyataan. Kesembilan pernyataan ini berkisar tentang gambar, warna, tata letak, plot cerita, karakter tokoh, nama tokoh, dan bahasa yang digunakan.

Uji validasi materi terdiri dari 6 pernyataan. Keenam pernyataan ini berkisar tentang isi cerita di komik yaitu pengetahuan baru yang didapat, konten yang mudah dibaca, konsep kata yang mudah dipahami, ada tidaknya pesan moral, keefektifan dalam menyampaikan informasi, dan keterbaruan yang mumpuni.

\section{Tahap Pengujian}

Pada tahap pengujian ini, kami menguji lewat kuesioner yang kemudian diolah dengan rumus sehingga bisa diketahui apakah Kolekbindo sudah layak atau belum dijadikan media sosialisasi. Sebelum kuesioner disebar secara daring, kami melakukan uji validitas kuesioner terlebih dahulu.

\section{HASIL DAN PEMBAHASAN}

\section{Analisis Kebutuhan Kolekbindo}

Sebelum Kolekbindo diciptakan, kami melakukan analisis terlebih dahulu mengenai persoalan seputar sosialisasi konsep kata yang baik dan benar. Kami mewawancarai 7 orang narasumber. Mereka semua setuju setuju bahwa sosialisasi konsep kata, khususnya konsep kata-kata baku bahasa Indonesia, yang dilakukan oleh instansi terkait yaitu Badan Pengembangan Bahasa dan Perbukuan belum cukup berhasil. Selain itu, karena kurangnya sosialisasi tersebut, mereka membutuhkan media yang kreatif dan inovatif serta dalam bentuk digital atau bisa diakses dengan mudah lewat internet.

Berdasarkan hasil wawancara di atas, kami berinisiatif untuk membuat sebuah media sosialisasi untuk membantu masyarakat lebih memahami konsep sebuah kata bahasa Indonesia bernama Kolekbindo.

\section{Produk Kolekbindo}

Komik leksikon bahasa Indonesia yang kami buat bernama Kolekbindo. Kolekbindo merupakan komik strip berisi cerita yang memvisualisasikan konsep suatu kata baku. Artinya, satu cerita terdiri dari 6-10 panel dengan plot ringan dan menarik. Pesan mengenai konsep kata baku disampaikan melalui dialog antartokoh yang fokus pada tiga tokoh utama, yaitu Mawa, Upit, dan Acis.

Wujud Kolekbindo berupa salinan digital yang dibagikan kepada masyarakat melalui media sosial. Kata yang akan dibahas pada setiap strip komiknya adalah kata-kata yang termasuk dalam laras umum, tulisan, formal, dan informal seperti gawai atau daring. 

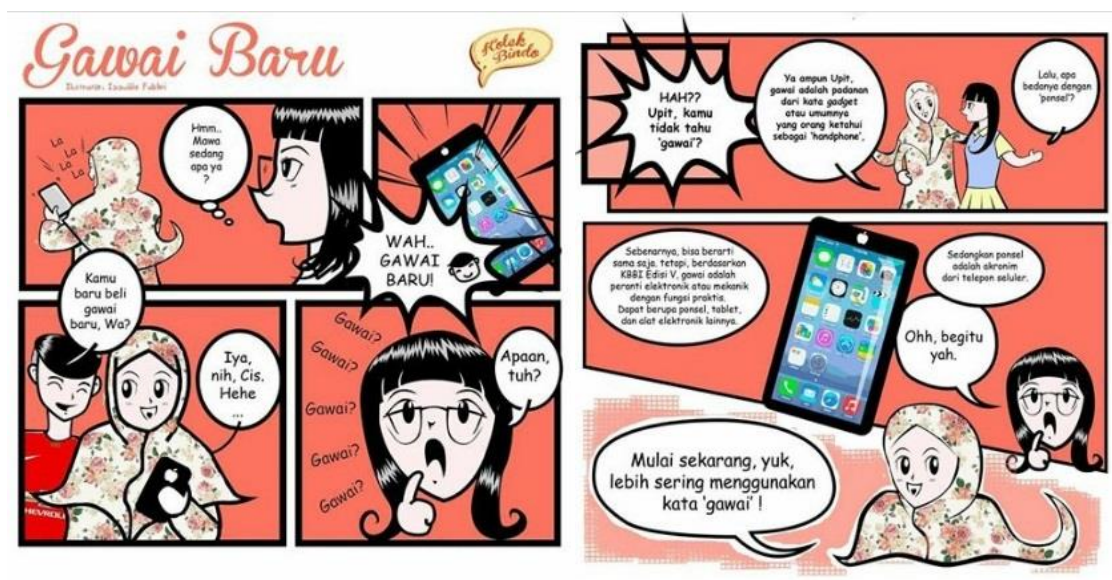

Gambar 8. Komik Unggahan Pertama Kolekbindo

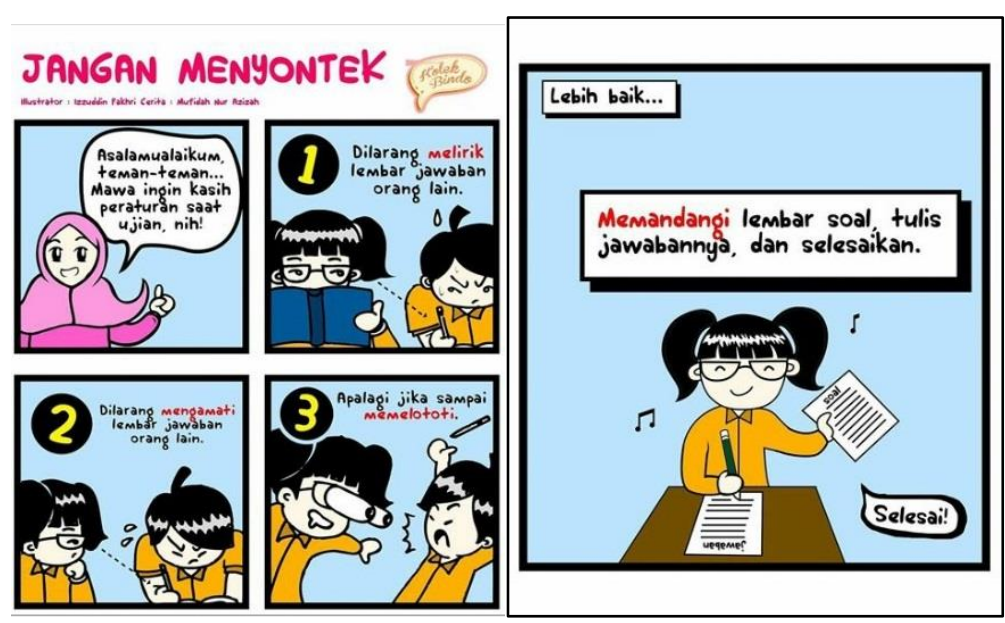

Gambar 9. Komik Unggahan Kedua Kolekbindo

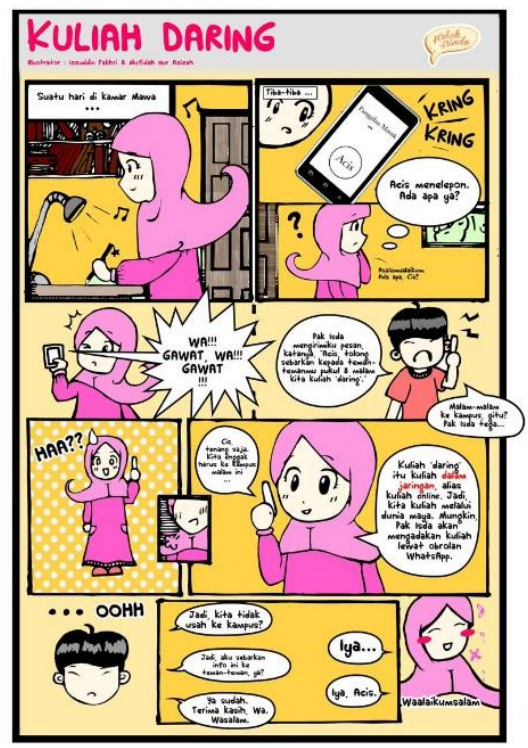

Gambar 10. Komik Unggahan Kolekbindo di Twitter 


\section{Validasi Kolekbindo}

Melalui validasi media pada 28 Agustus 2018, menyatakan skor akhirnya adalah 4,67 dengan kriteria sangat baik. Skor ini didapat dari 9 pernyataan yang diajukan seputar gambar, warna, tata letak, plot cerita, karakter, nama, dan bahasa yang digunakan.

Melalui validasi materi yang juga dilakukan pada 28 Agustus 2018, menyatakan skor akhirnya adalah 5 dengan kriteria sangat baik. Skor ini didapat dari 6 pernyataan yang diajukan seputar pengetahuan baru yang didapat, konten yang mudah dibaca, konsep kata yang mudah dipahami, ada tidaknya pesan moral, keefektifan menyampaikan informasi, dan inovasi yang mumpuni.

\section{Uji Coba Kolekbindo}

Lewat proses uji coba ini, kami bisa tahu apakah Kolekbindo sudah dinyatakan efektif atau belum sebagai media sosialisasi. Keefektifan ini ditinjau dari kuesioner yang kami bagikan lewat media sosial Instagram, Twitter, dan Facebook, dengan catatan mereka harus membaca terlebih dahulu komik di akun kami.

Responden yang ada di dalam penelitian ini sebanyak 37 orang dengan ketentuan sasaran yaitu masyarakat Indonesia pengguna internet, khususnya media sosial, dengan rentang usia 13 s.d. 34 tahun.

Kami mengajukan 15 pernyataan. Dari kelima belas pernyataan, hasilnya kami ubah ke dalam format persentase. Pernyataan nomor 15 "Kolekbindo adalah media sosialisasi yang inovatif dan kreatif." mendapatkan persentase tertinggi yaitu 94\%. Lalu, diikuti oleh nomor 10 "Kolekbindo memberi saya pengetahuan baru tentang kosakata dalam bahasa Indonesia" dengan 93\%. Nomor 11 "Konten yang ingin disampaikan dari Kolekbindo mudah dipahami" dengan persentase 91\%.

Kemudian, yang terendah adalah pernyataan nomor 2 yaitu "Warna pada Kolekbindo memiliki perpaduan yang menarik" dengan persentase $79 \%$.

Selanjutnya, untuk menentukan apakah Kolekbindo layak atau tidak untuk dijadikan media sosialisasi, akan dihitung lewat rumus berikut.

$$
\begin{aligned}
\mathrm{K} & =\frac{\text { skor semua responden }}{\text { jumlah responden } X \text { jumlah pernyataan }} \\
\mathrm{K} & =\frac{2384}{37 \times 15} \\
\mathrm{~K} & =4,30
\end{aligned}
$$

Dengan demikian, Kolekbindo sudah layak digunakan karena berada pada kriteria sangat baik dengan skor 4,30 dan persentase $85,80 \%$. Skor ini melebihi batas kriteria minimal yaitu 3,40.

\section{KESIMPULAN}

Kolekbindo merupakan media sosialisasi konsep kata-kata baku bahasa Indonesia yang dibuat untuk melengkapi keterbatasan produk-produk kebahasaan. Berdasarkan hasil penelitian ini, Kolekbindo telah melalui tahap validasi media dan mendapat skor sebesar 4,67 dengan kategori sangat baik, serta tahap validasi materi dengan hasil skor sebesar 5 dan berkategori sangat baik pula. Selanjutnya, Kolekbindo diujicobakan melalui kuesioner yang menghasilkan persentase sebesar 85,80\% dan skor sebesar 4,30 dengan kategori sangat baik. Maka dari itu, Kolekbindo sudah layak digunakan sebagai media sosialisasi konsep kata-kata baku bahasa Indonesia

\section{REFERENSI}

Artawan, Cokorda Alit dan Ni Ketut Rini Astuti. 2015. Kartun sebagai Elemen Visual Media Pembelajaran Lalu Lintas Ditlantas Polda Bali. Jurnal Segara Widya. 3(1). 418-427.

Chaer, Abdul. 1997. Tata Bahasa Praktis Bahasa Indonesia. Jakarta: Rineka Cipta.

Chaer, Abdul. 2007. Leksikologi dan Leksikografi Indonesia. Jakarta: Rineka Cipta. 
Chaer, Abdul. 2011. Ragam Bahasa Ilmiah. Jakarta: Rineka Cipta.

Catalina, Carla. 2017. Perancangan Kampanye Sosial Mencintai Bahasa Sunda sebagai Bahasa Ibu pada Anak melalui Media Komik [skripsi]. Bandung: Universitas Pasundan.

Fuchs, C. 2014. Social Media: A Critical Introduction. Los Angeles: Sage Publication, Ltd.

Kaplan, Andreas M. dan Michael Haenlein. 2010. Users of the World, Unite! The Challenges and Opportunities of Social Media. Business Horizons. 53(1). 59-68.

Kosasih, E. dan Wawan Hermawan. 2012. Bahasa Indonesia Berbasis Kepenulisan Karya Ilmiah dan Jurnal. Bandung: Thursina.

Kushartanti, Multamia RMT Lauder, dan Untung Yuwono. 2009. Cetakan Ketiga. Pesona Bahasa: Langkah Awal Memahami Linguistik. Jakarta: Gramedia Pustaka Utama.

Laughey, Dan. 2007. Key Themes in Media Theory. New York: Open University Press.

Lubis, Toras. 2013. Pengembangan Multimedia Pembelajaran Berbentuk Komik dengan Alur Cerita Berangkai untuk Identifikasi Lack of Knowledge Siswa dalam Memahami Mata Pelajaran TIK SMP [skripsi]. Bandung: Universitas Pendidikan Indonesia.

McCloud, Scott. 2001. Memahami Komik. Jakarta: Kepustakaan Gramedia Populer.

McQuail, Denis. 2003. Teori Komunikasi Massa. Jakarta: Erlangga.

Nurgiyantoro, Burhan. 2005. Sastra Anak Pengantar Pemahaman Dunia Anak. Yogyakarta: Universitas Gadjah Mada Press.

Pramitha, Dara. 2010. Sosialisasi Bahasa dalam Pembentukan Kepribadian Anak (Studi pada Orang Tua di Kelurahan Serpong Jaya Kecamatan Kedaton Bandar Lampung) [skripsi]. Lampung: Universitas Negeri Lampung.

Pranowo, Taufik Agung. 2017. Efektivitas Layanan Informasi melalui Komik Edukasi dalam Meningkatkan Motivasi Belajar Siswa MI Ma'arif Grabag Magelang. Jurnal Konseling Gusjigang. 3(1). 90-96.

Pravitasari, Tisa Ashifa, Ahmad Adib, dan Anang Tri Wahyudi. 2017. Perancangan Komik Digital mengenai Pengaruh Negatif Sosial Media pada Remaja Wanita di Surabaya. http://studentjournal.petra.ac.id/index.php/dkv/article/view/5517. Diunduh pada tanggal 12 April 2018.

Sasmita, Ongko, I.G.N. Ardana, dan Cons. Tri Handoko. 2013. Perancangan Komik Sosialisasi 4 Pilar Kehidupan Berbangsa untuk Remaja. http://studentjournal.petra.ac.id/. Diunduh pada tanggal 12 April 2018.

Setiawati, Sulis. 2016. Penggunaan Kamus Besar Bahasa Indonesia (KBBI) dalam Pembelajaran Kosakata Baku dan Tidak Baku pada Siswa Kelas IV SD. Jurnal Gramatika. 2. 44-51.

Sugiyono. 2013. Metode Penelitian Kuantitatif, Kualitatif, dan R\&D. Bandung: Alfabeta.

Sukmadinata, Nana Syaodih. 2010. Metode Penelitian Pendidikan. Bandung: Remaja Rosdakarya.

Suriasumantri, Jujun S. 1998. Filsafat Ilmu: Sebuah Pengantar Populer. Jakarta: Pustaka Sinar Harapan.

Waluyanto, Heru Dwi. 2005. Komik sebagai Media Komunikasi Visual Pembelajaran. Jurnal Nirwana. 7(1). 45-55.

Zulpiqar, Tio. 2016. Perancangan Karakter Tokoh dan Latar Suasana Cerita Rakyat Munding laya Dikusumah pada Buku Cerita Bergambar [skripsi]. Bandung: Universitas Pasundan. 